\title{
Human Dignity as the Foundation of the Patient-Physician Relationship
}

\section{Martina Pavelková}

\author{
Life is short, \\ and art long, \\ opportunity fleeting, \\ experience perilous, \\ and decision difficult. \\ (Hippocrates) ${ }^{1}$
}

\section{Introduction}

The patient-physician relationship has developed in history. In the Hippocratic Oath we read that the patient's health is most important (salus aegroti suprema lex). Gradually the approach emphasizing the patient's autonomy came to the forefront (voluntas aegroti suprema lex). In recent decades the patient-physician relationship has become complex not only due to advancements in medicine, but also due to growing expectations of patients. Earlier it was natural that some diseases were considered incurable. Today not curing these diseases is perceived as failure of curative medicine. Patients refuse to resign to an unfavourable diagnosis and look for an offender responsible for their state. Physicians themselves are often to blame, as they raise hopes in the unlimited possibilities of medicine (sometimes only because they cannot admit to themselves that their procedure has failed, that there is nothing more they can offer the patient).

In this paper we want to consider the patient-physician relationship, especially with respect to the situation in the Czech Republic, as defined by the relevant laws. In that we want to show the historical changeability of the patient-physician relationship, which is to a great extent determined by the conception of health and disease of the given historical period. We will also present contemporary models of the patient-physician relationship. By that we will highlight the difficulties and possibilities of this relationship, where the decisive foundation of its quality is human dignity.

\section{The patient-physician relationship - a matter of ethics, or law? ${ }^{2}$}

When the patient-physician relationship is discussed nowadays, the legal aspect of this relationship is usually meant. The physician must instruct the patient concerning her procedure and request his informed consent. Otherwise she could get in conflict with the law. There are many legal norms treating the patient-physician relationship and the number

1 Hippocrates's aphorism is more than 2500 years old and concisely covers various aspects of medicine: Medical art is based on a lengthy and in essence never concluded acquisition of knowledge; at the same time it depends on the right moment, which however quickly passes; it is based on uncertain attempts. Due to all that it is very difficult to make a right decision in medicine. 2 Of course there is also the view of economy, since the patient pays for the physician's services (at least through compulsory public health insurance). But the economical aspect, though not insignificant, is not a matter of interest here. 
of norms trying to cover the complexity of this relationship is growing constantly. While in the past medical issues were only marginal in law, at present there is talk of medical law as a discrete branch of law. ${ }^{3}$ The lawyer Tomáš Doležal analysed the patient-physician relationship from the legal-historical point of view and concluded that this relationship is of private-legal character. In the preface to his book he states that he was writing it at the time when the change of Law 20/1966 Sb., on care of public health - law on health services, was being prepared. At the time of these preparations information was leaking to the public saying that the old law "does not comply with the modern conception of the patient-physician relationship, is too paternalistic and does not take into account the autonomy of both subjects concerned - in short is a manifestation of the statism of the 1970s in ČSSR". ${ }^{4}$ One would therefore logically expect that the prepared new law will diverge from this publiclegal conception. That, however, did not happen and not even the new Law 372/2011 Sb., on health services, changed the view of the patient-physician relationship much, as it is still viewed in the public-legal plane..$^{5}$ In her everyday practice the physician is confronted with a number of legal regulations, which are often projections of (bio)ethical norms to the sphere of law. Of course there are ethical codes and conventions, but these - unless they are legally enforceable - are not taken too seriously by the physicians. The present legislature regulating the providing of health care is based on fundamental ethical principles, such as salus aegroti suprema lex (health of the patient is the highest law) or voluntas aegroti suprema lex (will of the patient is the highest law). The latter attitude slowly began to set through with the emphasis on human rights and autonomy of the individual. In order to understand the patient-physician relationship better we will sketch the historical transformations this relationship has undergone.

\section{Transformation of the patient-physician relationship}

In Antiquity, the Middle Ages and the Modern period perceptions of disease and health have changed much - and so has the related form of the patient-physician relationship. Different philosophical views and ethical principles have influenced medicine for centuries up to the present. Let us briefly describe the main features typical for each epoch. ${ }^{6}$

In Antiquity fundamental role was played by cosmology. The relationship of man to his own body was influenced by his relationship to nature. The image of man and nature determined the idea of health and disease. The patient-physician relationship is, characteristically for the age, depicted at the Ancient Roman burial ground in Ostia. There we find the image of a woman giving birth to a child into the hands of another woman and at the same time

3 The gradual permeation of health care topics to the sphere of law is cogently discussed by the Austrian lawyer Gerhard Köbler in his paper From Pbysician in Law to Medical Law. As breaking point he regards the year 1977 when the lawyer Adolf Laufs wrote a book of 110 pages called "Arztrecht". Cf. Gerhard KÖBLER, Vom Arzt im Recht zum Arztrecht, in: Humaniora: Medizin - Recht - Geschichte, Bern-Rüdiger KERN et al., Berlin-Heidelberg: Springer-Verlag, 2006, pp. 157-172.

4 Cf. Tomáš DOLEŽAL, Vitab lékaře a pacienta zpobledu soukromébo práva, Př́ibram: Leges, 2012, p. 9.

5 For completeness' sake let us add that even before this new law came to effect, it became the object of several constitutional complaints; when it came to effect the Czech Medical Chamber, Association of Patients of CR and Senate of CR strove for its further novelization. Approximately one year after coming to effect, the law was novelized (the change concerned primarily providing health services to minors).

6 We will primarily rely on the following works: Dietrich von ENGELHARDT, Die Arzt-Patient-Beziehung - gestern, heute, morgen, in: Die Arzt-Patient-Berziebung im Wandel, ed. Klaus ARNOLD, Stuttgart: Thieme, 1996, pp. 19-47; Dietrich von ENGELHARDT, Das Bild des Arztes in medizinhistorischer Sicht, in: Arat - Patient. Zur Geschichte und Bedeutung einer Beziebung, Tübingen: Attempto, 2001, pp. 31-42. 
is supported from behind by another woman. This image is a symbol of man-to-man help at a particular moment of his life. The physician Viktor von Weizsäcker had thus depicted medical art in mind when he said in the 20th century: "The basic image of medicine is a man in need and a man who helps." The patient-physician relationship was best reflected in the Hippocratic Oath, which for many centuries was determinative of physicians' behaviour. The physician was to respect the person of the ill man and was not to distinguish between child or old man, woman or man, free man or slave. This conception corresponded to the Christian understanding of equality of all before God. In fact, in Antiquity health and disease were perceived as physical and at the same time religious phenomena, since medicine and philosophy mutually influenced each other. Health and disease were not perceived merely as sensibly experienceable states, but had also philosophical consequences.

For mediaeval medicine the fundamental concept is transcendence. That means that the cosmological-anthropological approach is subordinated to the theological perspective. On this view God permitted disease only when it was beneficial for a man's soul. Disease was thus subordinated to the last end of man, was simultaneously conceived as an opportunity. Health and disease thus acquire salvation-historical meaning. They are related to the eschatological movement away from paradise (constitutio) through earthly existence (destitutio) to resurrection (restitutio). Through disease and healing every human realizes this universal process in himself. Disease is perceived as a necessary part of earthly existence and one must remember that despite all human effort it is not possible to be fully healthy here on earth. The final and complete healing of man will only occur through his salvation. To this understanding the patient-physician relationship corresponds. While the physician is an image of Christ who heals (Christus medicus), the ill person becomes an image of Christ's passion. Both patient and physician must accept the fact that earthly life is necessarily accompanied by disease, suffering and death. The ideal of a perfect state of health is a mere illusion and, we ought to say, a fairly dangerous illusion. ${ }^{8}$

In the modern age a new image of medicine begins to form, which still strongly influences us today. Disease becomes the object of medically objective analysis. With gradual secularisation disease begins to be conceived as a disruption of the function of the organs, as loss of individual and social abilities. At the beginning of the modern period Francis Bacon (1561-1626) predicted a great progress of medicine, which ought to be able to cope with diseases. René Descartes (1596-1650) compared an ill man to a mechanical clock out of order. He conceived the human body and nature in general in a mechanistic manner: like a clock is assembled of wheels and pendulums, so the human body is a kind of machine assembled of bones, nerves, muscles, blood vessels, blood and skin. Disease is conceived simply as an objective datum. The invention of the thermometer subsequently became a symbol of disease objectification. Of course, the technical understanding of disease as a defect of the organism also affected the patient-physician relationship. The patient-machine

7 Claus BUDDEBERG (ed.), Psychosoziale Medizin, Berlin-Heidelberg: Springer-Verlag, 2004, p. 345.

8 Here we can see a difference as compared to the contemporary bipolar understanding of health and disease - see the definition of health of the World Health Organization (WHO) as a state of complex physical, social and psychological well-being. This definition is too maximalist and creates a certain utopian idea of health. It is necessary to say that few people reach a state of "complex well-being" in their everyday life. The WHO definition must therefore be regarded rather as an ideal to be approached without reaching it. 
became an object examined, measured, described and repaired by the physician-mechanic. We must mention, however, that later voices came to be heard again calling for the humanization of the patient-physician relationship, whose ideal image we have seen captured in the picture in the Ancient Roman burial ground in Ostia. As we began our brief historical overview with a picture, so we may now close it off with another picture. The Spanish painter Francisco Goya in one of his works captured the basis of every relationship in the field of medicine (see the above mentioned words of Viktor von Weizsäcker) - on the one hand there is a man in need, on the other hand there is a man providing help. In the picture Goya captured himself with doctor Arrieta. Goya as patient is sitting in bed, holding on to the blanket, while from the behind he is propped up by his physician who gives him no pills but a glass of clear water. A physician's main task therefore ought to be accompanying the ill person, being close to him at the time of illness. We can now conclude the historical excursion into the patient-physician relationship with the words of Karl Jaspers, who, among other things, made a great contribution to ethos in medicine: "A physician is neither a technician, nor a saviour, he is a being for another, a transient being who together with others, in others and in himself realizes the freedom and dignity he regards as fundamental criteria." 9

\section{Four models of the patient-physician relationship}

At the very beginning we pointed out how important cooperation between physician and patient is. We then mentioned the historical transformations of this patient-physician cooperation. Various interactions take place between the two subjects of the relationship, which could be generalized based on their different character into four models. ${ }^{10}$

\section{Paternalistic model}

The first model is sometimes also called "fatherly" ${ }^{11}$ or "priestly", ${ }^{12}$ since the physician takes the part of one who best knows what is best for the patient's health and satisfaction. Based on her knowledge she evaluates the patient's situation and proposes the best procedure with respect to his state of health. Paternalism can be defined as "intentional omission of the preferences or acting of one person by another person, when the person omitting those preferences and acting justifies that acting by beneficence for or prevention of damage to the person whose preferences or acting have been omitted." ${ }^{13}$ Paternalism can further be divided into strong and weak. In weak paternalism the physician acts with the intention of warding off the patient's damage in case he is not capable of truly autonomous acting (persons who have not been adequately instructed concerning their state, persons suffering from a grave form of depression or persons who are for various reasons incapable of making a free decision - e.g. are under the influence of an addiction). In strong paternalism the physician intervenes in the patient's acting, even though he is adequately informed, is autonomous and acts freely.

\footnotetext{
9 Karl JASPERS, Ein Beispiel: ärztliche Therapie, in: Philosopbie, vol. 1, Berlin, 1932, pp. 121-129.

10 Cf. e.g. Ezekiel J. EMANUEL - Linda L. EMANUEL, Four models of the physician-patient relationship, The Journal of the American Medical Association 16/1992, pp. 2221-2226.

11 Gilman BURKE, Ethic and medical decision-making, Primary Care 7/1980, pp. 615-624.

12 Robert M. VEATCH, Models for ethical medicine in a revolutionary age, Hastings Cent Report 2/1972, pp. 3-5.

13 Tom L. BEAUCHAMP, James F. CHILDRESS, Principles of Biomedical Ethics, New York: Oxford University Press, 2001 , p. 176.
} 


\section{Informative model}

Another type of the patient-physician relationship is illustrated by the informative model, which can also be called "scientific" 14 or "engineering" 15 . In this model the physician's role consists in that she provides the patient with information concerning his state and possible interventions including possible risks related to them. The patient himself then selects the procedure he wants and the physician's task is merely to carry out the selected intervention well. In this model the physician is understood as a mere provider of services. In this model there is an evident difference between facts and values. The physician's duty is to inform the patient of all the available facts and the patient then selects a procedure best corresponding to the values he professes. Values professed by the physician play no part here. The physician thus finds herself in the role of a technical expert, who merely takes care that the patient's knowledge is as complete as possible.

\section{Explanative model}

In the third model the point is that the physician gets to know the patient's attitudes and wishes and helps him to find that solution among all accessible ones that best fits these values. As in the preceding model the physician must inform the patient of the character, conditions, advantages and risks of the procedure. But in the explainative model the point is also that the physician helps the patient express or sort out his value scale. The physician therefore takes also the part of a psychologist or psychotherapist, since sometimes it can be very difficult to detect the values endorsed by the patient and it is therefore necessary to explore the patient's life so far and find out his priorities. The patient realizes his autonomy by becoming better aware of his identity and selects the solution that best respects his personality.

\section{Deliberative model}

The last model places the greatest demands on the physician. The physician's task is to accompany the patient in an involved manner through the whole process of deliberation and help him reach a decision best corresponding to the patient's state of health and values. The physician together with the patient deliberate what values could or should orient the patient in selecting the best solution to his situation. In this model the physician could be compared to a friend who searches for what is best for the patient in dialogue. The physician not only presents possibilities, for which the patient can decide, she even should advise the patient as to which solution he ought to decide for. The patient's autonomy consists in moral self-determination, because the patient does not merely follow his preferences and values, but is willing - through dialogue with the physician - to mutually compare these values and consider their impact on the procedure process.

If we now compare all four models, we find out that each of them in some way assumes the patient's autonomy, but they differ in how it is conceived.

\section{Autonomy and patient's informed consent}

As the preceding lines have shown, autonomy is one of the central concepts of medical ethics. Fundamental for the origin of the ethical understanding of the concept of autonomy 
is the practical philosophy of Immanuel Kant (1724-1804). Following Kant's philosophy, autonomy in ethics is perceived as the free awareness of the human being, in which human responsibility becomes a necessary prerequisite of normative obligatory force. ${ }^{16}$ In a simplified way we could say that autonomy consists in the patient's free will (in the introduction to this text we have mentioned the ethical principle according to which will of the patient is the highest law). The term "patient's will" does not sound too familiar to the Czech reader cognizant of the legal regulation. Before 1989 we can hardly speak of the patient's will. ${ }^{17}$ Only in 2001 did autonomy of the patient find its way to our legal order in connection with endorsing the Convention on Human Rights and Biomedicine. We find it here in the form of the institute of informed consent of the patient. We must keep in mind, however, that a legal norm cannot automatically change the physician's value attitude to patient. Every physician is obliged by law to obtain the patient's informed consent before the intended intervention. But respect to the patient's autonomy requires not only obtaining the informed consent, but also engaging the patient in the very process of deliberating. In practice enforcing the informed consent is still difficult (although - or perhaps because - since accepting the institute of informed consent it has been made obligatory by a legal regulation). ${ }^{18}$ According to Tomáš Doležal two problems follow from this: a) in practice informed consent is on the part of the physicians perceived as an administrative obstacle in caring for the patient (this fact is easy to see in substituting conversations between physician and patient by reading a pre-printed form, which the patient in his state often signs without knowing what it is about), b) legal theory without exception adheres to the institute of informed consent, without taking into account partial changes that are necessary if informed consent is to be sustainable. Since the Czech Republic as compared to Western countries is markedly belated in accepting informed consent, we must solve problems that have already been solved in more developed countries and are not able to react to incentives brought by the dashing development of medicine, which significantly alter the understanding of informed consent. ${ }^{19}$ We find ourselves in the period in which the USA was in 1957-1972, which Beauchamp and Faden call Becoming Informed About Informed Consent. ${ }^{20}$ In the meantime legal theory in connection with biomedicine in the Western countries have become aware of a problem that can arise concerning informed consent in connection with the stormy development of

\footnotetext{
16 The concept of autonomy is also used in other disciplines (politics, psychology, law, pedagogy, sociology), where it has a rather different meaning. On the different meanings of the concept of autonomy cf. Monika BOBBERT - Micha H. WERNER, Autonomie/Selbstbestimmung, in: Handbuch Etbik und Recht der Forschung am Menschen, C. LENK et al., Berlin-Heidelberg: Springer-Verlag, 2014, pp. 105-114.

17 This situation is well illustrated in the communist cult series Nemocnice na kraji města, where the injured hockey player Přemysl Rezek requests an explanation of the medical procedure awaiting him so that he could decide whether to give his consent to it. The operating physician comes to him and silences him with the words "What consent? We simply must repair that head of yours."

18 In the USA a survey was conducted among practical physicians as well as expert specialists concerning their motivation for obtaining the patient's informed consent, which according to the law there a physician must obtain before carrying out a medical procedure. It was investigated what expectations they have of this, what their attitude to patient participation is and what they think of the character of the deliberative process. According to survey results most physicians welcome involving patients in the deliberative process. The patient's participation in the deliberation is perceived as a logical consequence of his autonomy. However, another frequent reason for involving the patient is also the principle of beneficence or physician's own interest to avoid being sued by the patient. Cf. Amy L. McGUIRE - Laurence B. McCULLOUGH - Susan C. WELLER - Simon N. WHITNEY, Missed Expectations? Physicians' Views of Patients' Participation in Medical Decision-Making, Medical Care 5/2005, pp. 466-470.

19 Cf. Tomáš DOLEŽAL, Problematické aspekty vztahu lékaře a pacienta zejména s ohledem na institut tzv. informovaného souhlasu, Časopis zdravotnickébo práva a bioetiky 1/2011, pp. 25-35.

20 Cf. Tom L. BEAUCHAMP - Ruth R. FADEN, A History and Theory of Informed Consent, Oxford - New York: Oxford University Press, 1986, pp. 88-100.
} 
medical science. There has come a period that we could call Retbinking Informed Consent, ${ }^{21}$ in which the concept of informed consent is being re-evaluated, because problems arise that cannot be solved within the partner-like patient-physician relationship. The situation now opens in front of us when we return to the concept of paternalism or neo-paternalism. This is due to the fact that the patient's decision can never be wholly autonomous, since his freedom can be determined by the following factors: ${ }^{22}$

- The patient's state - the patient usually contacts a physician in a situation when he is not well, is not healthy. ${ }^{23}$ Adam Doležal cogently describes this state with these words: "The patient finds himself in the position of fear, insecurity and pain. His Self's possibility of existence is limited by the external attack of illness, linked with pain, and thus he allows himself to be grasped by another existence, to which he entrusts his self. The physician's situation, on the other hand, is grasping, in the repeated act sometimes even routine, though done with maximum expert care, nonetheless essentially disinterested. The physician is thus in a position separated from an essential understanding of the anxiety of the Other Self, i.e., the patient's existence." ${ }^{24}$

- Impossibility of a wholly objective communication - the physician who is to provide the patient with information is in some way influenced by upbringing, religious creed, education. We can therefore ask whether "the information on the purpose and character of the procedure, as well as its consequences and risks is given to the patient always in pure form. For this information is always given by a person who has already formed a certain attitude framework concerning the matter at hand and from this point of view her information cannot be a purely objective statement of a fact, on the contrary it is already presented as a preselected position. And however objective the physician tries to be, he never steps out of his world. So although normative systems (legal and ethical, expressed by a professional code) require disinterested and proper informing, i.e., of all possibilities, such providing of information is not possible in the real extra-normative world." 25

- The physician is more professionally educated than the patient, which has the practical consequence that the patient in most cases accepts the procedure proposed by the physician.

- Objectivizing medicine - due to developing technology and ever more frequent legal regulations in medicine the possibility for the physician to think independently and devote herself fully to the patient, in whom she sees first of all a human being and not another medical case, is becoming progressively smaller.

- Narrow specialization of physician - every physician is an expert in her own discipline, but often lacks overlap to other fields, so that the information she provides to the patient can be marked by narrow specialization in a given field.

21 Cf. Jaime S. KING - Benjamin MOULTON, Rethinking Informed Consent: The Case for Shared Medical Decision- Making,

American Journal of Law \& Medicine 32/2006, pp. 429-501.

22 Cf. Tomáš DOLEŽAL, Problematické aspekty vztahu lékaře a pacienta, pp. 25-35.

23 Psychiatric patients are a distinct topic. In these cases there is conflict between the principle of care and respect for the patient's autonomy. In more detail on these situations cf. Martin Hans SASS, Advance Directives for Psychiatric Patients? Balancing Paternalism and Autonomy, Wiener Medizinische Wochenschrift 17-18/2003, pp. 380-384.

24 Adam DOLEŽAL, Informovaný souhlas jako vyjádření autonomie vůle nebo reflexe paternalistického vztahu?,

Časopis żdravotnického práva a bioetiky 1/2011, p. 8.

25 Ibid, p. 9. 
From what has been stated above it is evident that the institute of informed consent, which has barely managed to make itself at home in our legal system, carries along with it many pitfalls, which are necessarily projected on the relationship between the physician and the patient.

\section{Dignity as foundation of the patient-physician relationship}

We have seen that the patient-physician relationship is marked by a certain asymmetry. The physician on the one hand helps the patient and on the other hand discloses the secret of man, lays open his interior. She pronounces judgments on which it can depend whether a man will die or live. Like all who do well to others, physicians are exposed to both gratitude and hatred. ${ }^{26}$ Due to using technical means approaching patients as objects this hatred is further increased.

From the point of view of ethics it is necessary to focus on that the patient is perceived and respected as subject and as bomo absconditus. When hatred as an anthropological existential cannot be eliminated altogether, it must be directed by not increasing the patient's expectations and not supporting various saviour fantasies. ${ }^{27}$ It is necessary to try and create an environment of trust between patient and physician. The physician's trustworthiness and honesty are an ethical topic that is always relevant and ought to be emphasized. The fact that patient ought to trust his physician is also regarded as a matter of course. But less attention is paid to trust the physician should invest in the patient. The presence or absence of trust has both moral and practical consequences. The philosopher Wendy Rogers is convinced that physicians are actually obliged to trust their patients. ${ }^{28}$ It is evident that the physician must rely on the patient to a certain extent. She must rely on his statement of his subjective difficulties, based on which she proposes a procedure. In its course she must also rely on the patient's cooperation and his description of the course and state improvement. An exception is of course the situation, when the patient is not capable of cooperation - such cases may occur e.g. in urgent medicine or in the terminal stage of the patient's illness. Rogers compares trust to a lens tinting our view. If we trust someone, we interpret his behaviour in light of this trust. ${ }^{29}$ Closely related to trust is the concept of empathy. In particular there is talk of "clinical empathy", which "should frame the skills of all professionals who care for patients." ${ }^{30}$ We see that against disease-centred care there is patient-centred care. While scholarly papers are being written on empathy, in practice the objectifying attitude to the patient still prevails. ${ }^{31}$ Jaromír Matějek sees a problem already in educating future physicians at medical

26 In his work Religion Within the Bounds of Bare Reason, in chapter 3 entitled Man Is By Nature Evil, Kant writes of the human tendency to hate the one we are obliged to. Cf. Immanuel KANT, Náboženství v branicích poubébo rožumu, Praha: Vyšehrad, 2013, p. 75.

27 Cf. Knut BERNER, Der Hass auf die Wohltäter. Anthropologische und ethische Überlegungen zur Arzt-Patienten-Beziehung, Zeitschrift für medizinische Ethik 4/2012, pp. 327-339.

28 Cf. Wendy A. ROGERS, Is There a Moral Duty for Doctors to Trust Patients?, Journal of Medical Ethics 2/2002, pp. 77-80.

29 Cf. ibid, p. 77.

30 Howard M. SPIRO, What is Empathy and Can It Be Taught?, in: Empathy and the Practice of Medicine: Beyond Pills and the Scalpel, Howard M. SPIRO - Deborah St. JAMES, Yale University Press, 1996, pp. 7-14, at p. 7.

31 Cf. Rebecca GARDEN, The Problem of Empathy: Medicine and the Humanities, New Literary History 3/2007, pp. 551-567. 
schools, where a certain tension between medicine and the humanities is manifest. ${ }^{32}$ Even when we admit that the physician tries to respect the patient's autonomy as much as possible (by means of informed consent and with a minimization of factors that could pose a threat to the patient's autonomy), situations can occur in which the patient feels hurt in his dignity. Mile Bore describes the situation with the following words: "While the person might voluntarily agree to a medical procedure, be well informed of the procedure, have their records of the procedure kept in strict confidence, be unharmed by the procedure and actually benefit from the procedure, they might still incur and feel a loss of dignity." 33 We can therefore see that the concept of autonomy manifests itself as insufficient for capturing the core of the physician-patient relationship. The concept of human dignity shows itself as more useful..$^{34}$

Respecting human dignity means viewing the patient as an "end-in-itself" and not as a "case". Human dignity is the highest moral principle emphasizing the patient's free decision, in which the accompanying relationship between physician and patient culminates. ${ }^{35}$

It is necessary to distinguish between the concept of inherent and contingent dignity. Every human being has inherent dignity based on the fact that he is human. He cannot lose it, nor can it be diminished or taken away. It does not matter what position he has, how old he is, how rich or intelligent. On this concept of dignity human rights and equality of all humans before the law are based. Contingent dignity, on the other hand, is attributed to man from the outside based on his abilities, characteristics or social status. It is evident that illness and suffering can hurt man precisely in this type of dignity. Although man can never lose his inherent dignity, he can be very much hurt in contingent dignity. This must be remembered in the physician-patient relationship, especially in the stage of illness or old age in general when man is no longer able to perform functions he had no problems managing in health or youth. ${ }^{36}$

\footnotetext{
32 A problem is the fact that at contemporary medical schools medicine is perceived rather as applied biology of man. The physician is perceived rather as a natural scientist focusing on the anatomy and physiological processes in man, who somewhat misses other meanings or contexts that human illness brings. Cf. Jaromír MATĚJEK, Co je nemoc a proč si pacienti na nás pořád stěžují, Pediatrie pro praxi 1/2011, pp. 51-52.

33 (C) Miles R. BORE, Dignity: Not Useless, Just a Concept in Need of Greater Understanding, BMJ Rapid Responses, February 17, 2004 (on-line), at: http://www.bmj.com/rapid-response/2011/10/30/dignity-not-useless-just-concept-need-greater -understanding, retrieved November $28^{\text {th }}, 2015$.

34 The concept of dignity has achieved greater significance especially after World War II. In international law it has become a standard expressing respect to each man in all spheres of his life. Medicine is probably the most sensitive area, so it is no wonder that the concept of human dignity plays a central role here. In more detail on the concept of human dignity in international bioethical discussion cf. Roberto ANDORNO - Marcus DÜWELL, Der Menschenwürdebegriff in der Bioethik, in: Menschenwürde und Medizin: ein interdisziplinäres Handbuch, ed. Jan C. JOERDEN, Berlin: Duncker \& Humblot, 2013, pp. 465-481. Not all authors accept the concept of human dignity as necessary. In her paper "Dignity is a useless concept. It means no more than respect for persons or their autonomy" Ruth Macklin attempted to reduce human dignity to mere respect to the autonomy of man, whereby she labelled the concept of dignity as useless, to be left out of bioethical discourse. Cf. Ruth MACKLIN, Dignity is a useless concept. It means no more than respect for persons or their autonomy, BMJ 327/2003, pp. 1419-1420.

35 Cf. Ottfried HÖFFE, Medizin obne Etbik?, Frankfurt am Main: Suhrkamp, 2002, p. 49.

36 Cf. also Marta MUNZAROVÁ, Důstojnost člověka a lékařská etika, Časopis lékařu českých 9/2011, pp. 499-501; Marta MUNZAROVÁ, Důstojnost člověka v kontextu lékařství, in: Etika a komunikace v medicíně, Praha: Grada Publishing, 2011, pp. 51-58.
} 


\title{
Conclusion
}

In this text we have dealt with the ethical aspect of the patient-physician relationship. We have seen that in the past this relationship was of rather private-legal character, which is at present concealed by the ever growing legal regulation of the patient-physician relationship. Ethical principles are becoming enforceable legal norms, which brings along certain difficulties especially in the sphere of the institute of informed consent, in reflecting which the Czech Republic lags behind the Western countries and is forced to solve problems that the Western countries were tackling approximately fifty years ago. In the last decades the patient-physician relationship has also become more complicated not only by progress in medicine, but by the ever greater expectations of patients. Today not curing diseases considered lethal in the past is viewed as a failure of curative medicine. Patients acquire an ambivalent relationship to their physicians, because on the one hand they are obliged to them and on the other hand feel certain hatred towards them. The fault is also on the part of the physicians who raise hopes in unlimited possibilities of medicine (perhaps because they are incapable of admitting their own limited possibilities).

A way to prevent mutual disappointment is proper, open communication between physician and patient. This communication should be based on the ability to trust, empathy and respect to the patient's human dignity. Human dignity is the highest moral principle which respects the free decision of the patient as the culmination of the accompanying relationship between physician and patient. The patient should be viewed as an individual with his own will who needs help and the physician should be perceived as an expert who is here to try to help the patient, not do him harm.

\section{Human Dignity as the Foundation of the Patient-Physician Relationship}

\begin{abstract}
This article reflects the relationship between patient and physician, mainly with regard to the Czech law. The concept of health and disease in each historical period also influenced the patient-physician relationship. Different kinds of this relationship are demonstrated on four models. When we reflect the relationship between physician and patient, with all its difficulties and possibilities, we recognize human dignity as the basis of this relationship.
\end{abstract}

Keywords: physician, patient, relationship, human dignity, autonomy, informed consent

\section{Contact}

Mgr. Martina Pavelková

University of Souht Bohemia, České Budějovice

Faculty of Theology, Department of Ethics, Psychology and Charity Work

Kněžská 8, 37001 České Budějovice

Pavelkova.Martina@seznam.cz 